This is the accepted article in its pre-edited stage. Please refer to the published article in the journal Clothing Cultures https://www.intellectbooks.com/clothing-cultures 


\title{
A tale of two centuries: The körtti movement and dress in battles over Finnish politics and identities
}

Anna-Mari Almila

\begin{abstract}
This paper looks into the transforming sartorial styles of a certain Christian Protestant revivalist movement in Finland in and around two very specific historical moments: independence from Russia in 1917; and 2017, when the Marriage Act was amended such that same-sex marriage become legal. The analysis covers crucial periods before and after the independence: late $19^{\text {th }}$ and early $20^{\text {th }}$ century, when Russia sought to tighten its control over autonomous Finland, and the Finnish intelligentsia organised to resist such attempts, through the civil war of 1918, to the turbulent right/left-divided years of the 1920s and 1930s. Then, the liberalisation of the körtti movement from the 1960s and 1970s onwards, and the effect of this upon the debates and battles over the equal marriage law before and after the law came into effect is discussed.

I show how through changing histories, changing garments have the capacity to play key roles. By focussing on a particular movement through different times, it is shown how groups that go under the same name may be fundamentally different from their historical predecessors, how they may yet recognise a similar kind of garment even if they attach different kind of associations to it, and how new garments are sometimes required in order to communicate new positions of movements and individuals. For analyses of garments and cultural positions, this underlines the necessity to think of certain 'times' as part of a continuum, in which both changes and continuities in dress play out and influence socio-political relations.
\end{abstract}

Keywords: religious dress, Protestant revivalism, gay rights, same-sex marriage, Finland

\section{Introduction}

In times of unrest, garments are capable of both asking questions and providing answers. They can stabilise and provoke; they may unite and divide. In this paper, I look into the transforming sartorial styles of a certain Christian Protestant revivalist movement in and around two very specific historical moments: Finland's independence (from Russia) in 1917; and 2017, when the Marriage Act in Finland was amended such that same-sex marriage became legal. These are not arbitrarily picked examples, but are connected through a number of factors: battles over White/Red and liberal/conservative identities of people and the Nation; the fundamental intertwinedness of politics and religion; and reflections of all these factors in the 200-year history of the körtti movement and the dress preferences of its members.

The politics of dress, particularly in times of turbulence, such as revolutions, wars and other social unrest, have been discussed by many. Dress can be used in attempts to build appealing and powerful hegemonies, such as in case of fascism (Paulicelli 2004). It can work as a visualmaterial resistance and rejection of racialised hegemonies (Cosgrove 1984). Revolutions evoke new forms of attire (Ribeiro 1988), religious reformations call for distinction from old styles of dress (Murdock 2000), wars bring with them material rationing and ideological dress alike (Summers 2015), and sexual and gender struggles are both expressed through dress, and evoke 
moral panics in terms of styles and garments (Paoletti 2015). In terms of resistant, or oppositional, dress, Barnard (2002: 129) speaks of two kinds of resistance: 'Refusal is the attempt to step outside of the offending structures and reversal is the attempt to reverse the positions of power and privilege that operate within those structures'. But dress is used also by those who seek to defend their status and social position (Polhemus and Procter 1978). I here reflect upon two kinds of historical change: the changes in the character and image of the körtti movement itself, and changes in how garments associated with it are viewed, according to socio-political situation. I show how, as historical conditions change, social institutions and garments alike transform. Often, new garments expressing new identities emerge from such changes, too.

My analysis will cover crucial periods before and after the independence: late $19^{\text {th }}$ and early $20^{\text {th }}$ century, when Russia sought to tighten its control over autonomous Finland, and the Finnish intelligentsia organised to resist such attempts, through the civil war of 1918, to the turbulent right/left-divided years of the 1920s and 1930s. On the other hand, I will discuss the liberalisation of the körtti movement from the 1960s and 1970s onwards, and how this reflected upon the debates and battles over the equal marriage law before and after the law came into effect. I have elsewhere argued that each of the six phases of the movement's history -1) the time of emergence and sectarianism; 2) the time of dispersion; 3) the time of integration and nationalism; 4) the time of organisation; 5) the time of liberalisation; and 6) the time of the Church in crisis - has influenced differently dress strategies within the movement (Almila 2019). I here focus more on certain turbulent moments in history, and their significance in light of national politics as well as political battles within Finland's State Church.

\section{Methods}

I have used flexible qualitative methodological position in this research, combining different kinds of sources, both public and private, creatively. I draw upon archival and museum sources, namely written and image sources held by the Finnish Heritage Agency (https://www.museovirasto.fi/) and the University of Helsinki. I have also drawn upon written and image sources, as well as preserved garments and other objects, in the collections of the Körtti Museum in the town of Lapua (https://www.wanhakarhunmaki.fi/korttimuseo/) and the Lotta Svärd Museum in Tuusula (http://www.lottamuseo.fi/). An additional source has been my extended family's family albums and diaries.

I also gathered data through interviews and more informal conversations. My key informants were five people (three women, two men) who are actively participating in the movement, some of them working for the movement's central association, Herättäjä-Yhdistys, or for the Church itself. A further source were online platforms, as the körtti movement and many of its members today operate in virtual environments. These involve Instagram and Facebook, where the hashtags \#körtti and \#körttipuku (körtti dress) gave some useful results. In addition, I conducted searches in the main online discussion forum of the movement, Körttifoorumi (foorumi.h-y.fi). I have also followed the media coverage of the debates surrounding the position of the Church in terms of equal marriage law and wider sexual equality, and watched a relevant documentary film from 1960s reflecting the liberalisation of the movement (Anttikoski et al). All translations from Finnish are mine. 


\section{A short history of körtti and the körtti dress}

Körttiläisyys, or herännäisyys (awakening), is a revivalist movement within the Evangelical Lutheran Church of Finland, and a körtti (pl. körtit) is a member of said movement. The word körtti was initially a derogative term but was soon embraced by the 'awakened' themselves (Vilkuna 1928). Körttiläisyys derives from $18^{\text {th }}$ century Pietism, which was characterised by Christocentricity, practice of piety in everyday life, centrality of emotions, and collectivity (Lindt-Gollin 1967). European Pietist sects often withdrew from mainstream society (Weber 2002), and the same can to a certain extent be said of the Finnish movement: until the 1890s, it was considered crucial for the members of the movement to part with the company they kept previously (Vilkuna 1928), and this was easier to achieve when a sectarian dress drew strict boundaries between the 'awakened' and others (Almila 2019).

The time of emergence and sectarianism had its roots in the late $18^{\text {th }}$ century and reached its height in 1820s-1850s. This was a time when a distinctive sectarian dress was typically spontaneously donned upon 'awakening'. The time of dispersion, in 1860s-1880s, was marked by increasing withdrawal from mainstream religiosity. The körtti dress was used as a tool of control, and particularly imposed upon young children, in order to separate them from 'worldly' activities. The time of integration and nationalism, from the 1890 s onwards, reached its peak during and after WWI. During this time, the körtti movement came to be more integrated within the Church, but also deeply embedded in nationalist politics. Wearing the $k \ddot{o r t t i}$ dress as everyday wear was fairly common in parts of the country where the movement was prominent. The time of organisation partly overlapped with this: the movement started to publish religious material in 1888, and an annual gathering, Herättäjäjuhlat (awakening festival), was established in the early 1890s (Huhta 2007). The organization process reached its culmination after WWII in the founding of the Herättäjä-Yhdistys association (1945) that manages the movement today. At the same time, the custom of wearing the körtti dress all but vanished, especially among the young. The time of liberalisation, involving increasing urbanisation of the movement, took place from the 1960s-1970s onwards. Young left-wing clerics sought to sever ties with the right-wing political history and associations of the movement, arguing that the Church should be force for social good in society (Salomäki 2010). The time of the Church in crisis refers to the early $21^{\text {st }}$ century, when the Church has increasingly been challenged both by structural reformations within the Church and by external politics (Kirkon tutkimuskeskus 2012). The körtti movement has participated in debates about politicised issues, such as same-sex marriage, typically taking a liberal stance and defending equal rights and inclusivity. This is in line with the values of the members of the movement more generally today (Salomäki 2010). Yet, although liberal körttiläisyys is the most common revivalist affiliation among the employees of the Church, more conservative movements hold a strong position within the Church (Kirkon tutkimuskeskus 2012).

The körtti dress is said to have emerged in the 1820s in the Savonia area (eastern Finland) where Paavo Ruotsalainen (1777-1852), a farmer cum lay preacher, was an influential körtti leader. It thence spread to the Ostrobothnia (western Finland) area, when these two initially separate branches of Pietism came together (Vilkuna 1928). The dress style has changed during the years: shop-bought wool, cotton and blended materials have replaced home-span and woven wool, linen and hemp; black has come to be standardised instead of dark grey and blue. The male dress consists of a dark, short, stand-up collared jacket, trousers and a hat. In the back, the jacket has distinctive slits, 'körtit', clearly visible in Image 1 where körtti man and 
boy ascend the stairs of a church. The female dress has a dark short jacket and long skirt (initially wider and full-length, later shorter and narrower). A scarf was worn both on shoulders and on head. Both men and women parted their hair in the middle (Image 2) (for more details, see Almila 2019).

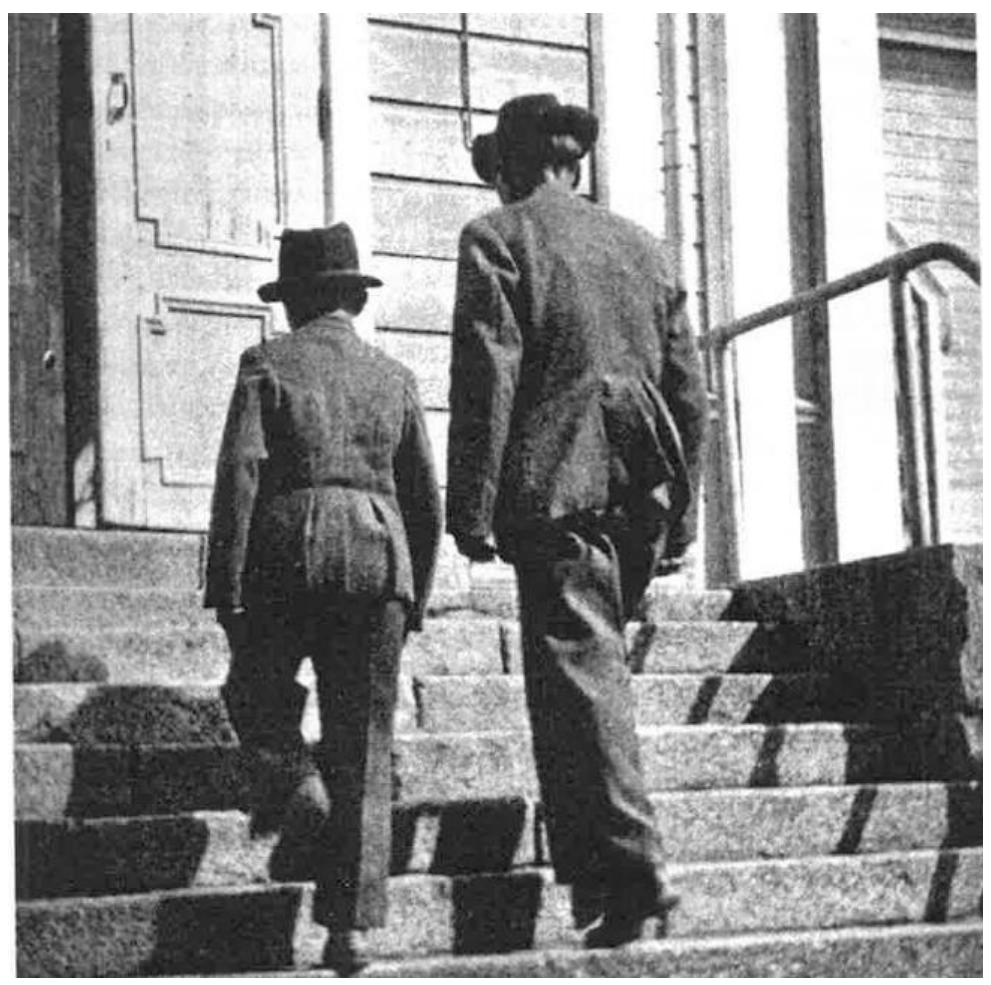

Image 1: Male körtti dress. Photograph: Wilhelmi Malmivaara (1854-1922).

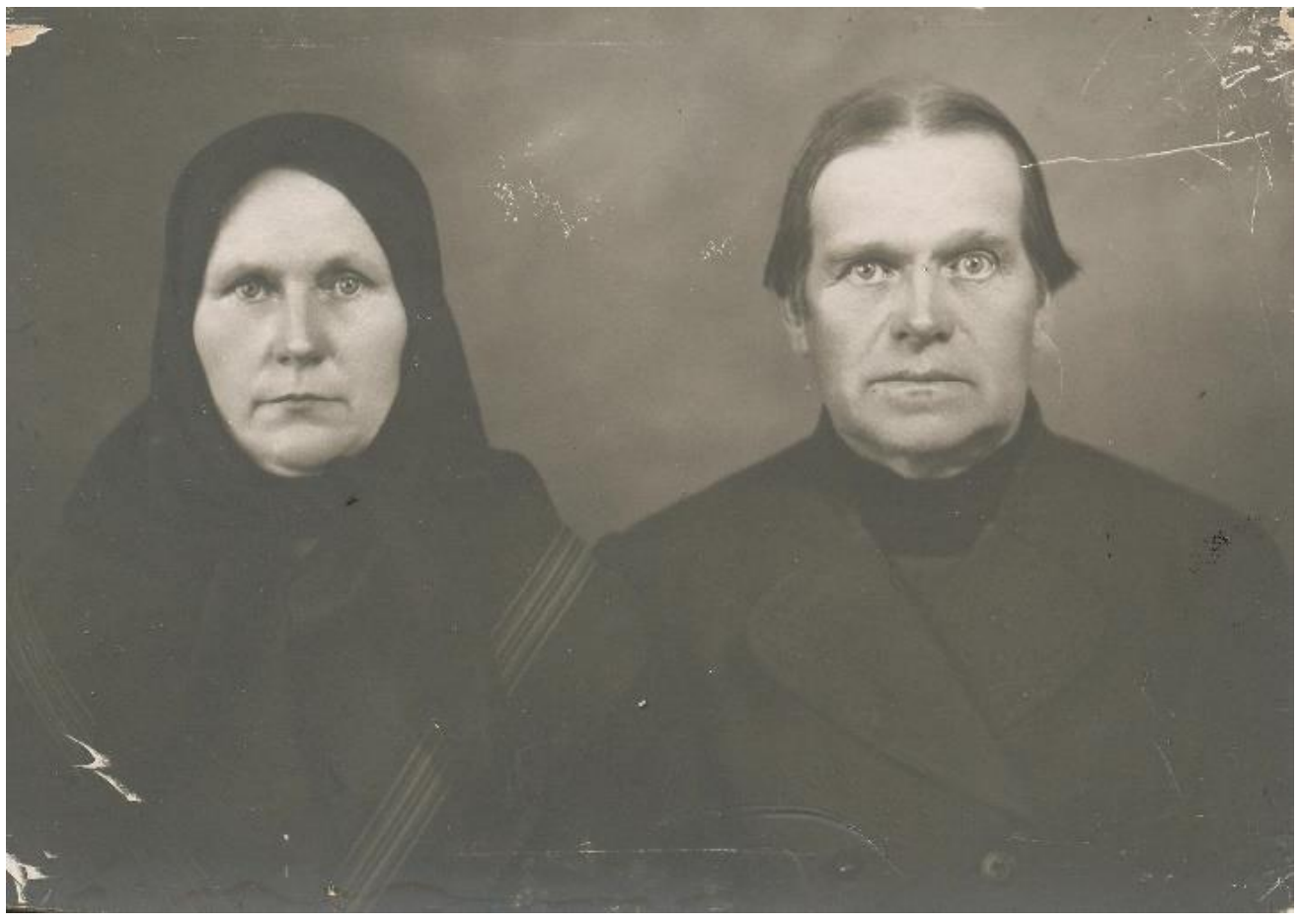

Image 2: Author's great-grandparents in körtti dress, c. 1920s/1930s. Photograph: family album. 
Old-fashioned already when it emerged, the körtti dress went against the trends of the $19^{\text {th }}$ century fashionable change. With increasing availability of textiles and garments and increasing industrialisation and wealth, Finnish wealthy peasants embraced new bright colours such as red in their garments. Lighter materials and tones, as well as ornamentation, were increasingly popular (Kopisto and Sihvo 1996). Members of the körtti movement, on the other hand, wore dark colours and modest, covering, form of dress, both for men and women. Fabrics were also typically thicker and heavier than the fashionable peasant dress of the time. Homewoven wools and linens were used still when other peasants increasingly favoured shop-bought fabrics as the $19^{\text {th }}$ century went on.

\section{White or Red? From Peasant Dress to Uniform}

From 1820 s to 1880 s, the körtti dress had been a symbol of separation from others, as the sect sought to protect itself and its members from 'worldly' influences. The dress originally derived from an (at the time) old-fashioned peasant dress and retained its rural connection throughout the $19^{\text {th }}$ century and well into the $20^{\text {th }}$ (Almila 2019). Towards the late $19^{\text {th }}$ century, a new generation of leaders, especially Wilhelmi Malmivaara (born Malmberg, 1854-1922), argued that the movement would be best located within the Church rather than outside of it. As the movement slowly came to be more acceptable in the eyes of the Church and others, it also gained a new kind of status as a representator of 'true', 'reliable' rural Finnishness. This was important, as during this time Russia sought to tighten its control over autonomous Finland, and the Fennoman intelligentsia were in need of nationalist ideals to resist such an external threat (Huhta 2007). The perceived homogeneity of the movement, expressed most powerfully in the körtti dress, was seen as a positive power against supposed 'selfishness' and individuality that threatened the unity of the people and the nation. This shift in views both within the movement and outside of it played an important part in what happened in 1917.

The Russian revolution in March 1917 was initially viewed positively by many in Finland, as it meant an end to Tsarist power that had increasingly oppressed Finland in the recent years. But during the spring and the summer, local mass strikes, socialist majority in the parliament and socialist activism changed the views of the Church as well as amongst the körtti movement. Social unrest was viewed negatively, and an external threat was replaced with an internal one: Finnish socialism and communism. As socialist demands included the separation of the state and the Church, freedom of religion, overturning of blasphemy laws, and taking over Church property (Huhta 2007), it was hardly a surprise that the Church viewed socialism in a negative light.

A Christian weekly paper Kotimaa (founded in 1905) published a special issue on körtti movement in 1917. In this, the movement was explicitly associated with the southern Ostrobothnian town of Lapua, a connection that came to be even more significant and meaningful in the upcoming years (as we will see). In the articles, social unrest came to be equated with giving up of one's faith and religion. Wrote Malmivaara:

Is it not peculiar that always when freedom from external oppression dawns upon the people of Finland, this freedom is used for separating the people from the God and his word[?] This was the case during the general strike [of 1905] and now again. (in Huhta 2007: 207) 
Nationalist papers, too, brought up the körtti movement as inspirational. Suomen Kuvalehti (founded in 1916) sent its reporter in 1917 to the Herättäjäjuhlat summer festival in Lapua, and she was deeply impressed by the dark-clad, homogeneous people she observed filling the outdoors venue (about 10000 participants from around Finland, according to estimates at the time):

In this era of hooliganism, cowardliness and selfish speculation one often asks oneself: where shall we be if this continues? Where are the people of Finland who still retain such chaste resources and backbone that it can guarantee us a new [economic] upswing? The Pietists have been the salt of our people and from their lot have risen many deep-rooted leader men. They have been customarily thought of with trust. (Jurva in Huhta 2007: 212)

Jurva's article was topped with a picture of four women in körtti dress (Image 3), presumably representing these reliable people of Finland. It is noticeable in the narratives about the körtti movement of this time that the value that the both the clergy and the wider Fennoman intelligentsia saw in the members of the movement was fundamentally bound up with the movement's loyalty to authorities and patriarchal power. One key indicator of this at the time was how the original ecstatic and emotional elements were excluded from religious practice, which also led to the exclusion of prominent female leadership that had previously been part of the movement (Sulkunen 1999). Emotionality and 'femininity' were apparently not considered suitable elements in nation-building. Thus the elements of desirable national characteristics were established as rural, modest, loyal, homogeneous, unemotional and nonsocialist in this frame.

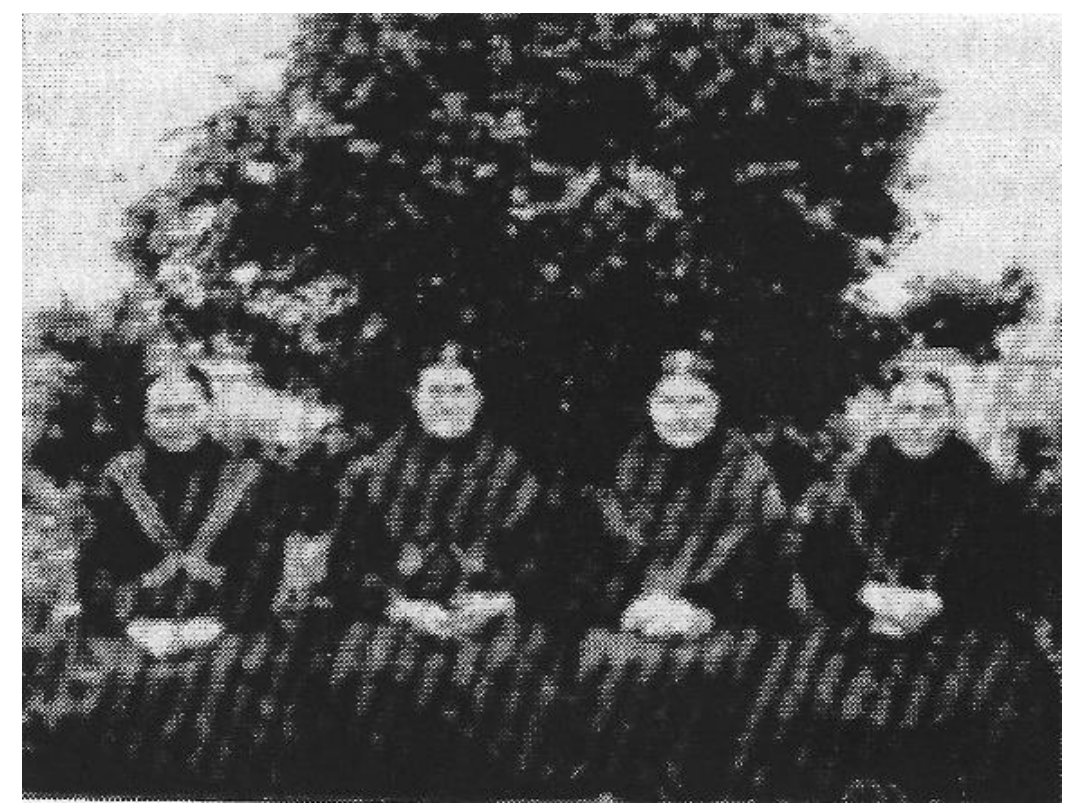

Image 3: körtti women in Lapua Herättäjäjuhlat, 1917. Photograph: Aura Jurva.

In the build-up to independence, voluntary military organisations had been established across Finland. These initiated as resistance against and protection from Russian troops, but soon came to be split according to white/red lines. A section of the White Guard, Suojeluskunnat, 
was established in the autumn of 1917 also in Lapua, at the local Karhunmäki school run by the körtti movement (Karhunmäen herännäisopisto). Military drilling came to be part of the school programme for male students (Huhta 2007).

When the civil war broke in early 1918, Karhunmäki students formed a körtti regiment on the white side. The distinctively dressed and behaving regiment soon gained a reputation as 'heroic' in battle. As they were from a Lapua school, they were all considered to be from the town, although in reality the students were from different parts of Finland. Lapua's violent, mythical histories (e.g. puukkojunkkarit, deviant men who in the $19^{\text {th }}$ century were involved in all sorts of crime, including theft and homicide) formed a background against which this new generation of men was reflected, and found exemplary for the needs of the whites in the civil war. The Christian weekly paper Uusi Suomi wrote in 1918:

When the körtti men move to attack, they never forget to pray before the start of the battle. [...] When the prayer is over, the awakened go to an attack with such an irresistible force and persistence that nothing can resist them. (in Huhta 2007: 218)

Meanwhile, the socialist paper Työmies had its own views of these 'awakened' soldiers:

Among the White Guard have with falsity and lies been agitated large groups of Ostrobothnian awakened, also the so called körtti. They are told to have [...] a black war flag, in which with large letters is drawn: In the name of Jesus Christ, against the devils. And their war cry is said to be: Knife to the right, knife to the left, knife into the breast of a Red. Horrible are these for slogans, but especially for Christians. (in Huhta 2007: 221)

Thus the körtti movement and the körtti dress both were thoroughly associated with antisocialism, anti-communism and the White Guards, and the (male) dress was embedded with more military associations than before. After the war, the male dress also underwent certain changes that made it appear more military and uniform-like. Sharp lapels appeared in the front, whereas previously there had been none (Vilkuna 1928). The appearance of the jacket and trousers came to be more tailored, especially when shop-bought fabrics came prominently to be used instead of home-made ones (Mäntykoski 1973). And the turns of sleeves that had previously been a distinctive characteristic disappeared, making the jacket more in line with mainstream male fashions (Vilkuna 1928).

Along with these changes in the dress and ideas about it, the male körtti dress came to be more representative of the movement, and more strictly established, than the female dress. Women's obligation to wear the dress as everyday wear disappeared fairly fast, so that the female körtti dress was soon only donned for celebrations and gatherings, both religious and worldly (Mäntykoski 1973). But men were expected to wear the dress as their daily attire. Still in 2007, a körtti man in his 80s explained the difference as follows in the Körttifoorumi online discussion group:

In my opinion, the körtti dress is no showcase. The man who wears it, the dress is his only formal dress which ever occasion he goes to.

For a woman the körtti dress is a completely different matter. For a woman it is just one dress in the wardrobe among others. You can wear it when you want to, when you consider the occasion appropriate. 
The civil war, won by the white side, left behind deep divisions between the whites and the reds. In the years following it, radical right-wing thinking and discourse won increasingly space in Finland. While the körtti movement was overwhelmingly right-wing, this was by no means a homogeneous position: some were moderate right-wingers, some nearer to agrarian centrist positions (Huhta 2007). But there was a strong stream of radical anti-communist right-wing position within the movement, too, especially in the southern Ostrobothnia area.

Towards the late 1920s, relations between the left and the right grew increasingly conflicted. Numerous fascist movements and organisations were founded, and anti-Communist legislation passed. The radical right Lapua Movement (Lapuan liike, LL), which emerged as a reaction to anti-Christian communist and socialist activism in 1929, and culminated in an attempted coup d'état in 1932, featured prominent members of the körtti movement. While the Lapua Movement emerged as a fairly spontaneous local activity, it soon turned violent and in many cases criminal, which draw more moderate members out of it. The members were guilty of numerous kidnappings (muilutus - kidnapping and transporting 'communists' (including social democrats) to the Soviet border) and even murder (Siltala 1985). The movement was banned in 1932 after the coup attempt, but was replaced immediately by the Patriotic People's Movement (PPM - Isänmaallinen kansanliike, IKL), a political party with the same leadership as the Lapua Movement (except for those who had been jailed for their part in the attempted coup). They went on to win modest representation in the Parliament in the three elections leading up to the WWII (Uola 1982).

The primary leader of the Lapua Movement, Vihtori Kosola, explained his choice of the emblematic colours for the movement: 'I designed the colours to be blue and black, for blue is the colour of the fatherland and black is a "fascist", anti-communist colour'. He also recognised that these were the colours of the 'awakened' but clamed no definite connection between the movements (Kosola 1935: pp.). The colours were used in a striking manner in summer 1930, during the 'Farmers' March' (Talonpoikaismarssi) demonstration in Helsinki. The demonstration was openly anti-communist, demanding the banning of numerous communist and socialist activities, and it was carefully coordinated and organised in line with right-wing and fascist principles: the route followed the victory parade of the whites in 1918, and the march was more generally inspired by the March of Rome (Marcia su Roma), which spiralled Mussolini in power in Italy in 1922 (Siltala 1985). Indeed, Kosola was sometimes considered the Mussolini of Finland. A popular slogan of the time 'heil Hitler, meil Kosola, muil Mussolini' means 'they’ve got Hitler, we've got Kosola, others have Mussolini'.

For reasons of ensuring order and safety, the 12000 anti-communist marchers were required to wear a blue-black armband on their left arm (Image 4). The bands were made by volunteers and paid for by a notorious madame, Minna Craucher, who had served as a fundraiser for the Lapua Movement (Bonäs 2012; Selén 1991). The march was received at the Senate Square by political and military leaders including the President and Prime Minister. During the rally, two körtti speakers delivered passionate speeches in defence of Christianity, against Communism: Kaarlo Kares (born Karl Präski, 1873-1942), one of the founders of the Lapua Movement, and Väinö Malmivaara (1879-1958), son of Wilhelmi Malmivaara who had been the central influencer in integrating the körtti movement within the Church. 


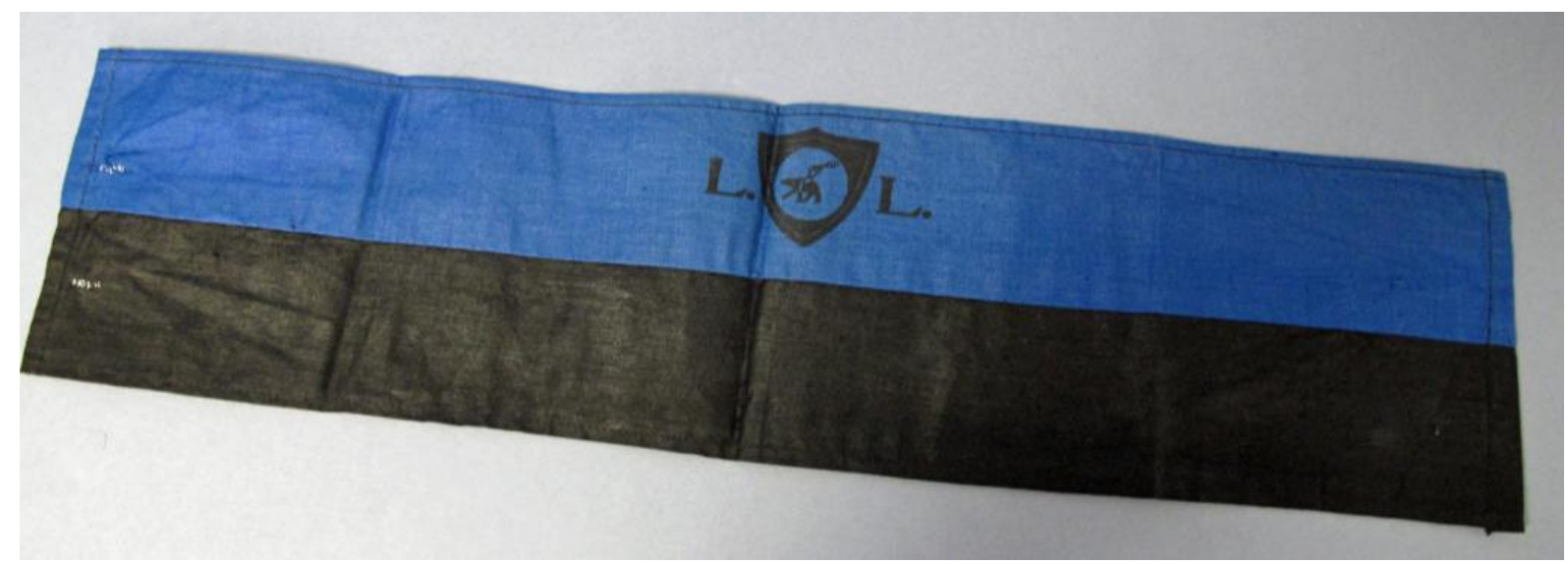

Image 4: The Farmers' March armband with the emblem of the Lapua Movement. In Lotta Svärd Museum's collection.

The youth organisation of the Lapua Movement, the Blue-Blacks (Sinimustat), was founded in a school in Lapua in 1930. Their uniform used the same colour theme: a black shirt and a blue tie (Image 5). While these openly fascist forces were growing and their operations turned increasingly anti-democracy, the state grew alarmed of their influence. Political symbols and uniforms were banned in schools in autumn 1933, despite many teachers being sympathetic to radical right aims (Konttinen n.d.). In 1934, 'shirt law' (puserolaki), a law banning political symbols in 'general gathering, amusement occasion, procession or while in public service' was introduced (132/1934). A decree extending this ban to all public spaces followed the same year (177/1934). Although the law was temporary, it was extended three times (431/1936; $452 / 1938 ; 971 / 1942)$, and the decree extended once (5/1937). Eventually the ban was in force until the end of 1945. The PPM MP Kaarlo Kares sought to challenge the ban in autumn 1936, but to no effect (TS 2008).

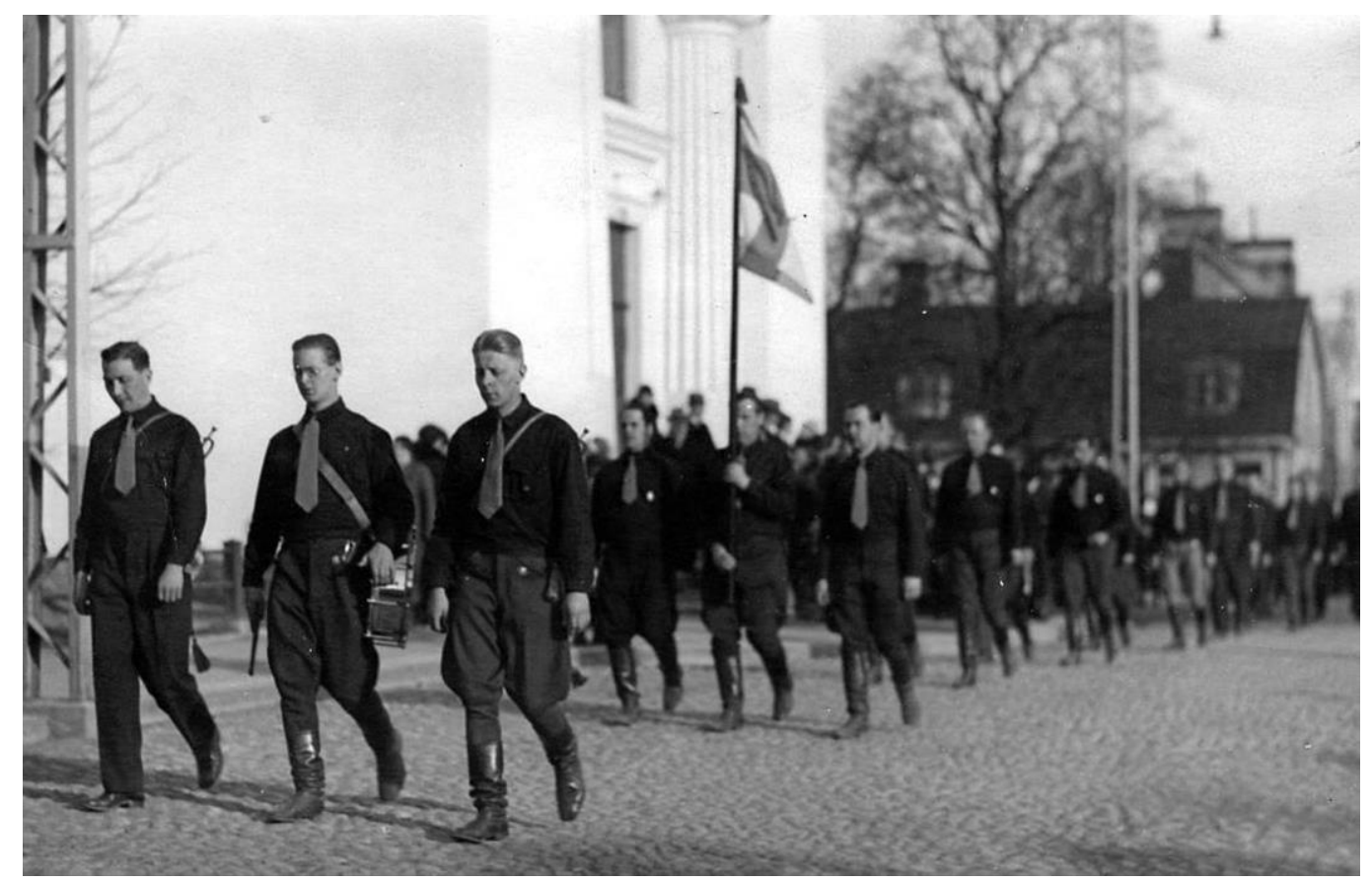

Image 5: Blue-Blacks marching in May 1933. Photograph: unknown. 
In late 1935, several leaders of the Blue-Blacks were found to have plotted a coup d'état in Estonia and the organisation was banned in 1936. It was soon replaced by the Blackshirts (Mustapaidat) organisation, which died out upon the start of the war in 1939 as all the Blackshirt youths were engaged in war preparations (Silvennoinen et al 2016). Some of these youth, including young körtti men, went on later to voluntarily serve in Nazi Germany during Finland's allegiance with the country (Konttinen n.d.). All fascist organisations and their symbols were forbidden by the Moscow Armistice signed in September 1944 - this included PPM who at the time still had representation in the Parliament.

The ban on political symbols and uniforms in schools survived until 1968. Upon its overturning, the principal of Lapua Lyceum (Lapuan yhteislyseo), Paavo Huhtala, claimed that 'those black shirts and blue-black symbols didn't cause any disturbance, rather the other way around' while admitting that the Blue-Black boys were 'spirited' and some conflicts happened (Yle 2013: n.p.).

Blue and black still carry fascist connotations for many today. This is evident in debates around so called 'Vihtori' pullover (named after Vihtori Kosola) (Image 6). In early 2010s, a National Coalition politician Susanna Koski was challenged for wearing the pullover in political pictures, and she claimed the garment to be a körtti shirt, and to have nothing to do with the Lapua Movement. However, this was denied by Herättäjä-Yhdistys. Their representative Kalle Hiltunen acknowledged that while the association with the körtti scarf (Image 7) is understandable due to the colour combination, the pullover is definitely not a körtti garment (Sarkimaa 2013). Historically, the pullover had been made publicly associated with the Lapua Movement by Vihtori Kosola wearing it in photographs in the 1930s (SS 2010).

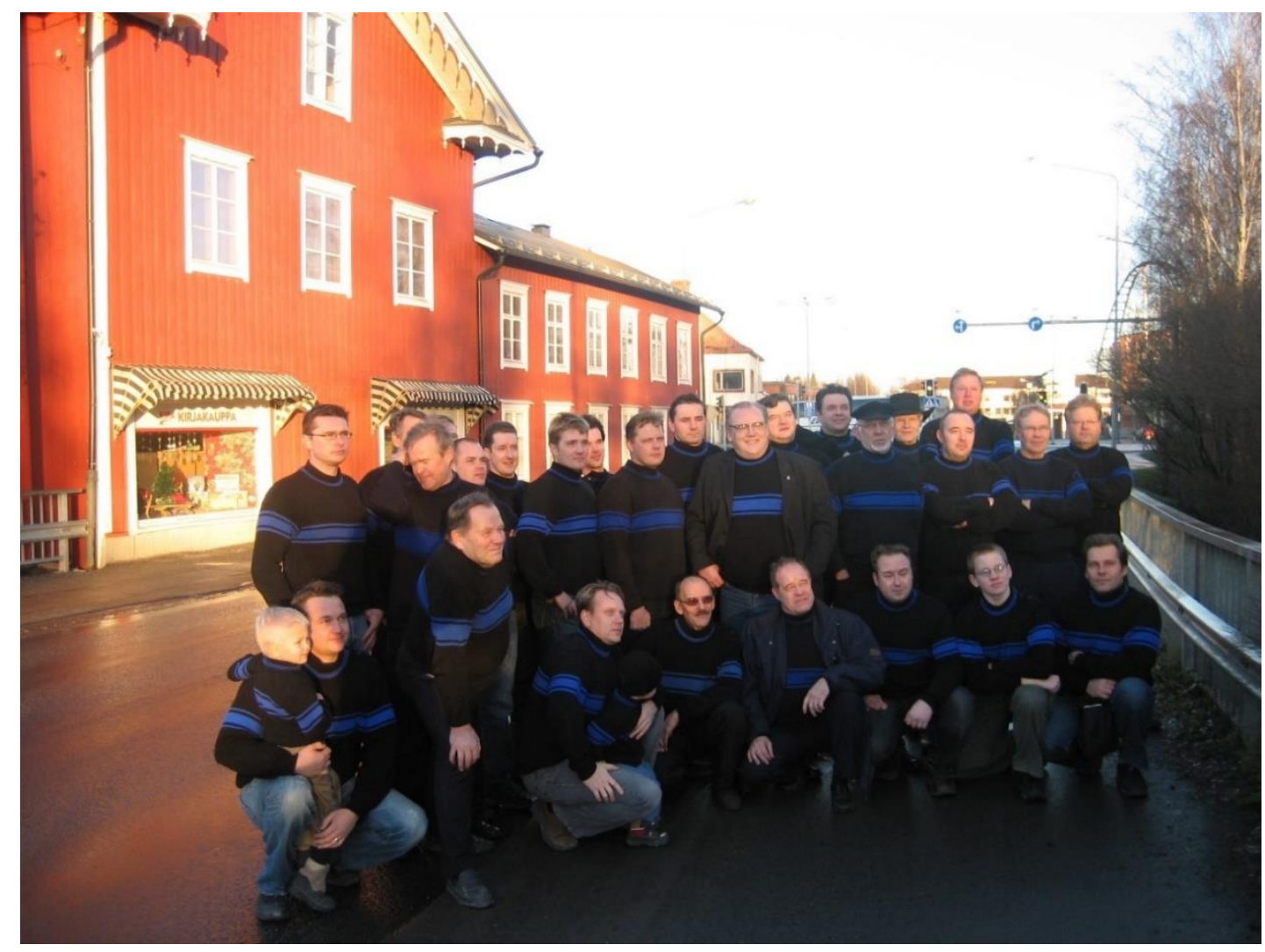

Image 6: Men wearing Vihtori pullovers in Lapua in early 2000s. In the background, the former home of Vihtori Kosola, now the headquarters of Herättäjä-Yhdistys. 


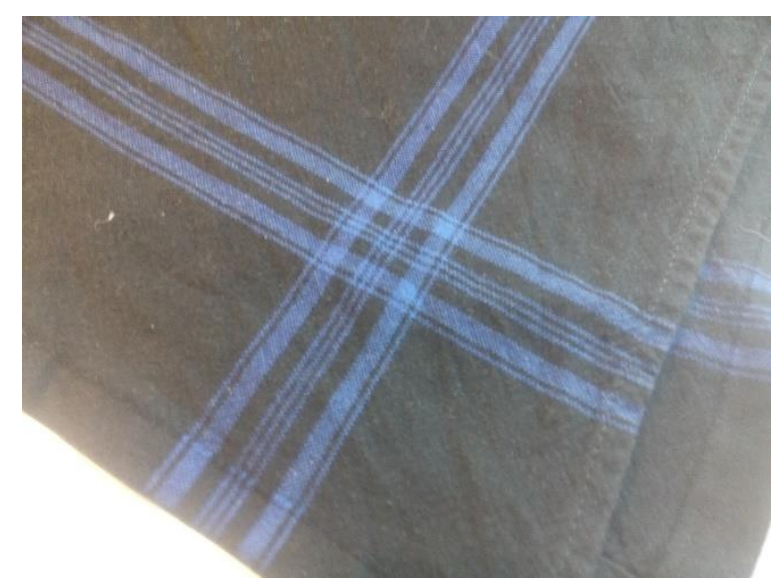

Image 7: Körtti scarf, as sold by Herättäjä-Yhdistys today. Photograph: author.

Today, this pullover is sold by Lapua Movement shop, which certainly was controversial when it opened as part of a Lapua Movement museum in 2007 (SS 2010). The garment is considered 'traditional' by many locals - a strategy of removing political connotations from it, which is possible as the garment was never 'official' Lapua Movement shirt. A Lapua-based blogger, who herself identifies as körtti, wrote in 2013 that to 'fuss' about the radical right history of this garment is pointless, and that it is popular among many locals and moderate right-wing politicians alike (Karhumäki 2013). As we will see below, the körtti movement has struggled to dissociate itself from its past in terms of right-wing radicalism. The distinction today seems to have succeeded fairly well. One member of the movement recently wrote in the Körttifoorumi discussion forum:

I was once given a blue-black PPM 'Vihtori' pullover, but I've never worn it as I find the ideology associated with it less pleasant. The körtti dress I could don without being ashamed of the spiritual ideology associated with it.

\section{Liberal or Conservative? From Radical Right to Gay Rights}

In March 2017, same-sex marriage became legal in Finland. In summer 2018, the youth work section of Herättäjä-Yhdistys, Nuori Yty, launched a t-shirt where a hymn citation from the körtti hymn book, Siionin Virret (Hymns of Zion), was printed in rainbow colours: armon valo voittaa (the light of mercy shall be victorious). According to Mika Nuorva of Nuori Yty (personal communication), this was a conscious statement supporting gay rights, and it was also read as such by members of the movement: it was associated with openness of the Church towards everyone (Image 8). To understand the nature of this sartorial statement, we must look into the politics around the equal marriage act and the Church, as well as within the körtti movement itself. 


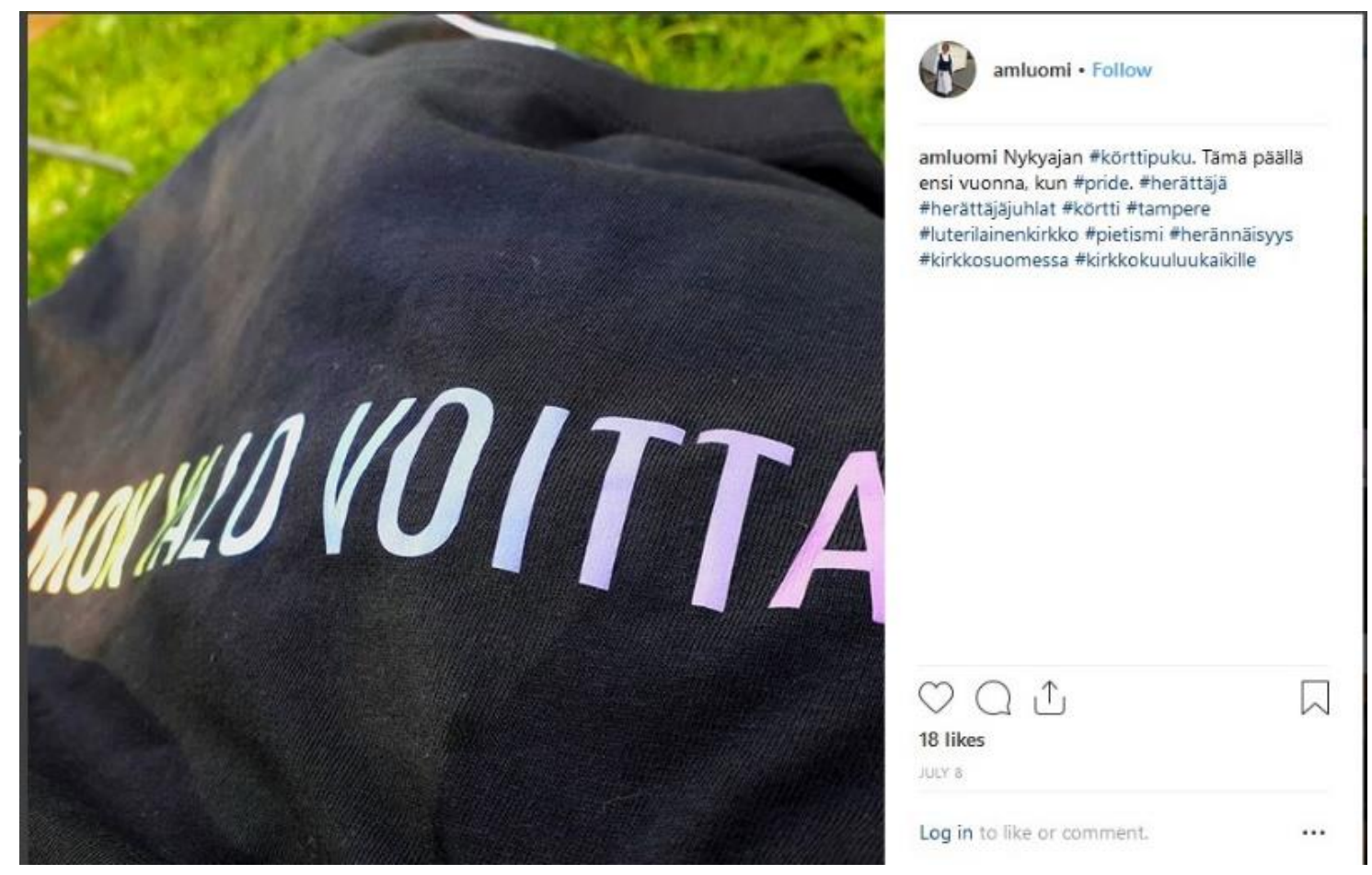

Image 8: Armon valo voittaa t-shirt. Hashtags include nykyajan \#körttipuku (modern körtti dress), \#pride and \#kirkkokuuluukaikille (the church belongs to everyone). Photograph courtesy of @amluomi

In the 1960s and 1970s, the körtti movement went through a wave of liberalisation, driven by left-wing clerics seeking to challenge the right-wing association of the movement in previous years. Two members of the movement reflected upon this in a 1960s documentary film (Anttikoski et al 1960s). Clergyman Olavi Kares, son of the fascist Kaarle Kares mentioned above, stressed that there had occurred a rethinking of guilt in terms of the civil war - away from blaming the Red side alone. Another clergyman, Olavi Kaukola, argued that the movement had in fact historically been highly egalitarian in its nature of peasant protest movement (see also Author 2019). In line with these kinds of views, members of the movement today are likely to stress that it is not the role of a Christian to judge anyone. Today, the körtti movement is undeniably the most liberal of the five revivalist movements operating within the Church (Salomäki 2010).

The Church has struggled with gay rights throughout the 2000s and 2010s. Same-sex civil union was legalised in Finland in March 2002. Several parliamentary initiatives between 2006 and 2012 sought to legalise same-sex marriage, facing Christian Democrat and other conservative resistance. Finally, by citizens' initiative ${ }^{1}$ in 2013,166851 signatures were collected, and the act moved into Parliament (https://www.kansalaisaloite.fi/fi/aloite/192). Most parties allowed their MPs a free vote in the matter, and thereby the act passed in 2014. Same-sex marriage has been legal in Finland since March 2017.

\footnotetext{
${ }^{1}$ Since March 2012, it has been possible to propose laws through citizens' initiative, which obliges the Parliament to consider the law if the minimum of 50000 confirmed signatures is collected in 6 months.
} 
Already in 2003, the Church felt there was need for a stance in this matter. A committee was set to evaluate the question and they recommended that special prayer occasions could be arranged in support of those Church members who had formed a civil union. The Bishop's Conference approved of this in 2010 and gave guidance upon how to arrange such prayers in 2011 (Kirkon tutkimuskeskus 2012: 307). But conservative forces within the church were not happy.

In October 2010, a TV debate called 'homoilta' (gay night) was arranged by the national broadcast company Yleisradio (Yle 2010). One of the people invited to discuss the topic was Päivi Räsänen, a hard-line conservative Christian Democratic politician. The homophobic views she expressed during the debate provoked an unprecedented wave of escape from the Church. In two days, over 4500 members left the church, and altogether during the year, the Church lost 2\% of its members (Kirkon tutkimuskeskus 2012). While most of the members who indicated their reason for leaving considered the Church too conservative, a minority left because they thought the Church too liberal. This reflects the dilemma the Church is dealing with today: 'the religiously passive majority expects a change in moral views, an active minority that they are kept as they are' (Kirkon tutkimuskeskus 2012: 381).

Since the equal marriage law came into effect, the Church has faced a new challenge. As an institution entitled to perform legally binding marriage ceremonies, it has had to take a stance in terms of gay marriage. While the Church formally forbids its clergy to marry same-sex couples, if such a ceremony is performed, it is legally valid. Ministers who have married samesex couples have been disciplined for the actions (Yle 2017) - but such censoring has recently been declared illegal in the eyes of law (Yle 2019). Meanwhile, the attitudes of the clergy have become increasingly liberal: more than half of them would marry a same-sex couple if allowed to do so by the Church (Yle 2018).

Yet conservative forces hold a powerful position in the Church. There have recently been attacks against the liberal Kirkko ja Kaupunki (Church and the City) weekly paper in form of funding cuts. On one occasion, a conservative younger male candidate was chosen over a more qualified senior liberal female one for one of the highest governance roles within the Church. Accusations of gender discrimination and bias have been expressed by many: 'Behind [the selection for the post] is an attitude towards same-sex marriage. [Candidate Aulikki] Mäkinen is considered to be modern' (Member of the Board of Directors for the Church Tarja Kantola in Lehtinen 2019a: n.p.). This nomination is considered by many as part of wider discriminatory structures, which involve both anti-gay and anti-women attitudes. Allegations of wide-spread gender discrimination and acceptance of openly anti-gay speeches and sermons have been made: 'One must say that church politics play strong role in decisions like this, although we live in year 2019 and [the Church] is a public entity that stresses openness, justice and equality' (anonymous cleric in Lehtinen 2019b: n.p.).

In June 2019, the Board of Governors for the Church announced that the Church officially supports Pride 2019 (four members opposed). This provoked an outcry from number of organisations and individuals active within the Church (Toivanen 2019). Rather ironically, Päivi Räsänen who had herself provoked large numbers of liberal individuals to leave the Church, threatened to leave the Church herself. Some revivalist movements, too, might be likely to sever their ties with the Church if it continues its liberalisation (Yle 2019). Many of the religious movements within the Church are strongly and explicitly anti-gay. Some of them 
have been active in anti-gay campaigns, such as 'älä alistu' (don't submit) and 'aito avioliitto' (real marriage). Meanwhile, Herättäjä-Yhdistys announced it would organise 'sateenkaariseurat' (rainbow gathering) religious meeting on the Sunday of the Pride week (Rytkönen 2019). And, I am told by an informant, a young körtti dress attired man attended the Nivala Herättäjäjuhlat festival with a rainbow-coloured umbrella. In light of these debates, what might seem to an outsider a harmless, hardly noticeable t-shirt, is in fact at the heart of the battle over the soul of the Evangelical Lutheran Church of Finland.

In this frame, the körtti pride t-shirt is an act of reversal, an attempt to change power and privilege structures (while those who leave the Church practise refusal) (Barnard 2002). An act of visible resistance to conservative forces, the t-shirt provokes different kinds of reactions in different parts of the country - and these are in line with attitudes in the areas more generally. In the Church elections ${ }^{2}$ of 2018 , there was a clear liberal victory in Helsinki, but increasing polarisation in many other cities (including Espoo and Vantaa of the Greater Helsinki area): both liberals and conservatives gained in the elections (Seppälä 2018). Therefore it is no great surprise that one of my informants tells me she has met with direct incredulity when wearing her t-shirt in a small town in south-western Finland: the fact that such a t-shirt is sold by a Christian religious movements seems unbelievable to some.

There have been public supportive statements towards sexual minorities within the körtti movement at least since 2005 (Huttunen 2005). Reading through the Körttifoorumi discussion forum, it is obvious that reactions towards homosexuality within the movement are very moderate, also amongst those with more conservative views. In Helsinki, the pride t-shirt fits very well with the liberal atmosphere and attitudes within the Church - and indeed, it was the chosen campaign outfit for one Helsinki-based candidate for the 2018 Church elections. At the same time, the garment also speaks of geographical and political divisions: some of my informants self-identify as 'city körtti', stressing their difference from (some elements of) the history of the movement. Therefore the interfaces of politics and religion continue to be channelled through garments such as the pride t-shirt, which communicates the geographical, political and religious divisions, and also makes those divisions visible and tangible.

\section{Conclusion}

Through changing histories, changing garments have the capacity to play key roles, and perhaps particularly so in times of unrest when symbolic meanings may become especially poignant and loaded. It is relevant here how the symbolic meaning of a dress is viewed by its wearers and others - are the previous and current associations so strong that they only change reluctantly, can some associations be transformed or removed, can history be partly forgotten, or at least forgiven? When discussing politics and religion - realms of power struggle and deep commitment and attachment - garments often come to play vital roles. They both spell out divisions and belongings, and build such boundaries, too. While the körtti movement is a unique case in a specific geographic setting, it speaks of much wider socio-political structures: nationalism and nation-building, religious belief and power, human rights and inclusivity. This case further encourages fashion scholarship to take seemingly mundane dress phenomena very

\footnotetext{
${ }^{2}$ Some governing bodies of the Church, formed of both clerics and laypersons, are elected by the members of the Church.
} 
seriously, as they are never separate of the surrounding conditions but instead reveal much about historical change and continuity.

Instead of looking at just one specific era of social turmoil, I have chosen to look into a particular movement through different times. This kind of approach has shown strikingly how groups that go under the same name may be fundamentally different from their historical predecessors, how they may yet recognise a similar kind of garment even if they attach different kind of associations to it, and how new garments are sometimes required in order to communicate new positions of movements and individuals. For analyses of garments and cultural positions, this underlines the necessity to think of certain 'times' as part of a continuum, in which both changes and continuities in dress play out and influence sociopolitical relations. Reflexive and creative ways of thinking about histories in this regard is an essential requirement for new insights for dress and fashion scholarship.

\section{References}

Almila, A. (2019), 'From protestant peasant dress to gay pride t-shirt: transformations in sartorial strategy amongst the körtti movement in Finland,' Religions.

Anttikoski, M. et al (1960s), Körttiläiset. Documentary, Yle TV2, https://yle.fi/aihe/artikkeli/2008/04/10/korttilaiset\#media=29776, accessed $1^{\text {st }}$ July 2019.

Barnard, M. (2002), Fashion as Communication, London: Routledge.

Bonäs, J. (2012), Kommunistskräck, konservativ reaktion eller medveten bondepolitik? Svenskösterbottniska bönder inför Lapporörelsen sommaren 1930, Åbo: Åbo Akademis förlag.

Cosgrove, S. (1984), 'The Zoot-Suit and Style Warfare', History Workshop, 18,pp.77-91.

Huhta, I. (2007) “Täällä on oikea Suomenkansa” Körttiläisyyden julkisuuskuva 1880-1918. Helsinki: Suomen kirkkohistoriallinen seura.

Huttunen, J. (2005), 'Körttijuhlat päättyvät aina penkinkantoon', Kirkko ja Kaupunki, $13^{\text {th }}$ July.

Karhumäki, H. (2013), 'Närkästys Lapuan sinimustista on tarpeetonta vouhotusta', Uusi Suomi, $28^{\text {th }}$ November, http://helikarhumaki.puheenvuoro.uusisuomi.fi/155009-närkästyslapuan-sinimustista-on-tarpeetonta-vouhotusta, accessed 1 July 2019.

Kirkon tutkimuskeskus (2012), Haastettu kirkko: Suomen evankellis-luterilainen kirkko vuosina 2008-2011, Helsinki: Kirkon tutkimuskeskus.

Konttinen, P. (n.d.), Muistoja ja mietteita, Self-published.

Kopisto, S. and Sihvo, P. (1996), Puku Suomessa 1750-1900, Helsinki: Museovirasto.

Kosola, V. (1935), Viimeistä piirtoa myöten, Lapua: Lapuan kirjapaino.

Lehtinen, T. (2019a), 'Kirkossa kuohuu: Korkeaan virkaan valittiin esittelijän miespuolinen kaveri tohtorinaisen sijaan', Helsingin Sanomat, 23 ${ }^{\text {rd }}$ May, https://www.hs.fi/kotimaa/art2000006115399.html, accessed $23^{\text {rd }}$ May 2019. 
Lehtinen, T. (2019b), 'Kirkossa pelataan kovaa valtapeliä, jonka kuluessa ratkaistaan suhtautuminen homoihin ja naisiin', Helsingin Sanomat, $6^{\text {th }}$ June, https://www.hs.fi/kotimaa/art-2000006132523.html, accessed $6^{\text {th }}$ May 2019.

Lindt-Gollin G. (1967), 'The religious factor in social change: Max Weber and the Moravian Paradox', Archives de sociologie des religions, 23,pp.91-97.

Mäntykoski, M. (1973), Körttipuvun käyttö ja merkitys Nurmossa 1800-luvulta nykypäiviin, Unpublished MA thesis, University of Helsinki.

Murdock, G. (2000), 'Dressed To Repress? Protestant Clerical Dress and the Regulation of Morality in Early Modern Europe', Fashion Theory, 4:2,pp.179-199

Paoletti, J.B. (2015), Sex and Unisex: Fashion, Feminism, and the Sexual Revolution, Indiana University Press

Paulicelli, E. (2004), Fashion under Fascism, Oxford: Berg.

Polhemus, T. and Procter, L. (1978), Fashion \& Anti-Fashion, London: Thames and Hudson.

Ribeiro, A. (1988), Fashion in the French Revolution, London: Batsford.

Rytkönen, J. (2019), 'Herättäjä-Yhdistys järjestää sateenkaariseurat Pride-viikon päätteeksi Helsingissä', Kotimaa 24, $7^{\text {th }}$ June, https://www.kotimaa24.fi/artikkeli/herattaja-yhdistysjarjestaa-sateenkaariseurat-pride-viikon-paatteeksi-helsingissa/, accessed $6^{\text {th }}$ July 2019.

Salomäki, H. (2010), Herätysliikkeissin sitoutuminen ja osallistuminen, Helsinki: Kirkon tutkimuskeskus.

Sarkimaa, S. (2013), 'Lapuan liike peri Mussolinilta sinimustan paidan värit', Kotimaa $24,6^{\text {th }}$ October, https://www.kotimaa24.fi/artikkeli/lapuan-liike-peri-mussolinilta-sinimustanpaidan-varit/, accessed 1 July 2019.

Selén, K. (1991), Madame: Minna Craucherin levoton elämä, Helsinki: WSOY.

Seppälä, O. (2018) 'Kärjistyykö vastakkainasettelu? - Seurakuntavaaleissa voittivat sekä konservatiivit että liberaalit', Kotimaa 24, $23^{\text {rd }}$ November, https://www.kotimaa24.fi/artikkeli/karjistyyko-vastakkainasettelu-seurakuntavaaleissavoittivat-seka-konservatiivit-etta-liberaalit/, accessed $10^{\text {th }}$ November 2019.

Siltala, J. (1985), Lapuan liike ja kyyditykset 1930, Helsinki: Otava.

Silvennoinen, O., Tikka, M. and Roselius, A. (2016), Suomalaiset fasistit : mustan sarastuksen airuet, Helsinki: WSOY.

SS (2010), “'Kosolan paita" on Lapuan liikkeen hittituote', Seinäjoen Sanomat, $23^{\text {rd }}$ October, https://www.seinajoensanomat.fi/artikkeli/5446-kosolan-paita-on-lapuan-liikkeen-hittituote, accessed 25 June 2019.

Sulkunen, I. (1999), Liisa Eerikintytär ja hurmosliikkeet 1700- ja 1800-luvulla, Helsinki: Gaudeamus.

Toivanen, M. (2019), 'Konservatiivisten järjestöjen johtajat liittyvät kannanotossa kirkon Pride-kumppanuutta moittivaan rintamaan', Kotimaa $24,25^{\text {th }}$ June, 
https://www.kotimaa24.fi/artikkeli/konservatiivisten-jarjestojen-johtajat-liittyvatkannanotossa-kirkon-pride-kumppanuutta-moittivaan-r/, accessed $6^{\text {th }}$ July 2019.

TS (2008), 'Puserolaki sääteli kansalaisten pukeutumista 1930-luvulla', Turun Sanomat, $20^{\text {th }}$ September,

https://www.ts.fi/uutiset/kotimaa/1074307521/Puserolaki+saateli+kansalaisten+pukeutumista +1930luvulla, accessed $1^{\text {st }}$ July 2019.

Uola, M. (1982), Sinimusta veljeskunta - Isänmaallinen kansanliike 1932-1944, Helsinki: Otava.

Vilkuna, K. (1928), 'Heränneiden körttipuku', in Etelä-Pohjalaisen Osakunnan julkaisu: Kyrönmaa II, Helsinki: Sana.

Weber M. (2002), The Protestant ethic and the spirit of capitalism, London: Blackwell.

Yle (2010), 'Ajankohtaisen kakkosen homoillat', Yleisradio, $19^{\text {th }}$ October,

https://yle.fi/aihe/artikkeli/2010/10/19/ajankohtaisen-kakkosen-homoillat, accessed $15^{\text {th }}$ June 2019.

-- (2013), 'Puserolaki ja poliittisten paitojen muotinäytös', Yleisradio, $18^{\text {th }}$ September, https://yle.fi/aihe/artikkeli/2013/09/18/puserolaki-ja-poliittisten-paitojen-muotinaytos, accessed 1 July 2019.

-- (2017), 'Pastori vihki homoparin - sai kirjallisen varoituksen', Yleisradio, $3^{\text {rd }}$ October, https://yle.fi/uutiset/3-9863764, accessed $4^{\text {th }}$ April 2019.

-- (2018), 'Pappien suvaitsevaisuus nousussa: enemmistö kannattaa homoparien vihkimistä', Yleisradio, $17^{\text {th }}$ October, https://yle.fi/uutiset/3-10462007, accessed $4^{\text {th }}$ April 2019.

-- (2019), 'Päivi Räsäsen ja arkkipiispan kirjeenvaihto toi taas pintaan kirkon ristiriidat avioliitosta - tutkija ei usko pikaisiin muutoksiin', Yleisradio, $20^{\text {th }}$ June,

https://yle.fi/uutiset/3-10841679, accessed 20 $0^{\text {th }}$ June 2019. 